\title{
Plantain silage quality under variable management practices
}

\author{
N.R. BARIROH ${ }^{1,2}$, R.H. BRYANT ${ }^{1}$ and A.D. BLACK ${ }^{1}$ \\ ${ }^{1}$ Faculty of Agriculture and Life Sciences, PO Box 85084, Lincoln University. \\ Lincoln 7647, Christchurch, New Zealand \\ ${ }^{2}$ Indonesian Agency for Agricultural Research and Development, Ministry of Agriculture, \\ Jl.Ragunan 29 Pasar Minggu Jakarta Selatan 12540, Indonesia \\ Nurrizqi.bariroh@lincolnuni.ac.nz
}

\begin{abstract}
Two studies investigated the effect of regrowth and additives on preservation and quality of plantain ensiled in spring using a micro-silage technique. Study 1 compared the effect of regrowth at four (4L), five (5L) or six leaf (6L) appearance. Study 2 compared fertilisers: $20 \mathrm{~kg} \mathrm{~N} / \mathrm{ha}(20 \mathrm{~N}), 20 \mathrm{~N}$ plus potassium and phosphorus (20NPK) or $40 \mathrm{~kg} \mathrm{~N} / \mathrm{ha}$ with $\mathrm{P}$ and $\mathrm{K}$ (40NPK) and additives: cellulose enzyme (ENZ), molasses (MOL), Biosil (BIO) or no additives (CON). After 180 days, wet chemistry was performed on all silages. Silages were dark brown and had a sweet smell, though fermentation was limited with an average $\mathrm{pH}$ of 5.2 and 5.8 in Study 1 and 2, respectively. However, $\mathrm{pH}$ declined $(\mathrm{P}<0.05)$ with early harvest, and use of $\mathrm{N}$ fertiliser or additives. Harvesting plantain for silage following a long regrowth is not recommended as the high stem content at this time contributed to low crude protein and low digestibility.
\end{abstract}

Keywords: Plantago lanceolata, nitrogen, inoculant, lactic acid

\section{Introduction}

For New Zealand farming systems, harvesting pasture for ensiling is an effective means of managing feed surpluses. The ensiled pasture, whether stored in a pit or wrapped as baleage, provides a cost-effective feed source during periods of feed deficit. To successfully ensile forages so that they may be stored and safely fed to livestock months later requires rapid removal of air so that reduction in $\mathrm{pH}$ via the production of lactic acid can occur, and maintenance of an anaerobic environment. Low $\mathrm{pH}$ caused by lactic acid preserves the forage preventing accumulation of harmful bacteria (Bolsen et al. 1996). Management factors which have shown to influence silage preservation and quality include: use of additives (Chamberlain \& Robertson 1992; Kleinmans et al. 2011), regrowth interval and $\mathrm{N}$ fertilisation (Jacobs et al. 1998). Consequently, the protocols for ensiling ryegrass-based pastures are well established.

However, less is understood about the ensiling properties of alternative pasture species. The increasing adoption of forage plantain (Plantago lanceolata) into conventional pasture systems for nitrogen (N) loss mitigation (Woods et al. 2016; Box et al. 2016), emphasises the need for information on its management and conservation. There is little information on plantain silage; only one report was found that suggested plantain can be ensiled, but compared with ryegrass and lucerne (Medicago sativa) silages, plantain silage has lower digestibility (Raeside et al. 2012). The current study investigated the effects of management practises that influence preservation and quality of plantain silage.

\section{Methods}

\section{Experimental site and treatments}

Two experiments investigating the effects of regrowth interval (Study 1), fertiliser and additives (Study 2) on plantain silage, were conducted under irrigation at the Lincoln University Research Dairy Farm, Canterbury, New Zealand (43⒍'S, $\left.172^{\circ} 46^{\prime} \mathrm{E}\right)$. The plantain pastures (cultivar 'Tonic') were established following cultivation in March 2014 and were rotationally grazed with dairy cows (Box et al. 2017). On 14th November 2016 the experimental area for both studies $(0.60 \mathrm{ha})$ was mown to $6 \mathrm{~cm}$.

\section{Study 1}

Study 1 was a completely randomised design with three stages of maturity of plantain and five silo replicates. The plant maturity stages were defined as four (4L), five $(5 \mathrm{~L})$ and six $(6 \mathrm{~L})$ leaves $(\mathrm{L}) /$ plantain tiller. After mowing, urea fertiliser was applied at $25 \mathrm{~kg} \mathrm{~N} / \mathrm{ha}$ and the area left to regrow until silage harvest on 14th, 21 st and 28th of December corresponding to the $4 \mathrm{~L}$, $5 \mathrm{~L}$ and $6 \mathrm{~L}$ growth stages, respectively. Mowing took place between 1300 and $1400 \mathrm{~h}$ and herbage was wilted for 24-48 $\mathrm{h}$ or when herbage passed the "squeeze test" as described by Moran (2005). Dry matter content (\%) was determined by oven-drying a subsample of $50 \mathrm{~g}$ fresh weight $(\mathrm{FW})$ for $48 \mathrm{~h}$ at $60^{\circ} \mathrm{C}$. Approximately $500 \mathrm{~g}$ of wilted plantain (leaf and stem, weeds and legume were discarded) was pressed firmly into a $23 \mathrm{x}$ $38 \mathrm{~cm}$ plastic bag to remove any air. The mini silo was inserted into a second plastic bag which also had the air removed and all bags were then stored in black plastic drums in a shed for 180 days. 


\section{Study 2}

Study 2 utilised a split-plot design with two fertiliser and three additive treatments and four blocks (replicates). The main plot fertiliser treatments were: $\mathrm{N}$ only at 20 $\mathrm{kg} / \mathrm{ha}$ as urea $(46 \% \mathrm{~N}),(20 \mathrm{~N}) ; \mathrm{N}, \mathrm{P}$ and $\mathrm{K}$ at $20: 1: 15 \mathrm{~kg} /$ ha (20NPK), and N, P and K at 40:1:15 kg/ha (40NPK). The sub-plot additive treatments were: no additives $(\mathrm{CON})$, cellulose enzyme (ENZ), Biosil, (BIO) and molasses (MOL). After mowing on 14th November 2016, treatment plots (each $10 \mathrm{~m}^{2}$ ) were marked and the fertiliser treatments were applied by hand to designated plots. On 27 December 2016, all plots were mown to $6 \mathrm{~cm}$ height at $1600 \mathrm{~h}$ and ensiled once the herbage passed the "squeeze test".

Additives were made up to solutions and mixed with the forage immediately before ensiling as described in Study 1. Cellulose enzyme (Sigma Aldrich) was added at $125 \mathrm{mg} / 500 \mathrm{~g}$ wilted plantain (Tengerdy et al. 1991). The commercial product Biosil (combination of cellulase, hemicellulase, amylase and beta glucanase) was made as $1 \mathrm{mg} / \mathrm{ml}$ and $2 \mathrm{ml}$ applied to $500 \mathrm{~g}$ of wilted plantain. Molasses was added to wilted plantain at $10 \mathrm{ml} / 500 \mathrm{~g}$ as recommended by Bolsen et al. (1996).

\section{Silage analysis}

After 180 days storage the mini-silos were visually assessed and the proportion of mould on the external surface area estimated. Upon opening the bags the

Table 1 Effects of regrowth stage on fermentation characteristic of plantain silage.

\begin{tabular}{lccccc}
\hline Parameter & 4L & 5L & 6L & SEM & P value \\
\hline $\mathrm{pH}$ & $5.13^{\mathrm{a}}$ & $5.00^{\mathrm{a}}$ & $5.52^{\mathrm{b}}$ & 0.06 & $<0.001$ \\
$\mathrm{BC}(\mathrm{meq} / 100 \mathrm{~g} \mathrm{DM})$ & $146^{\mathrm{a}}$ & $210^{\mathrm{b}}$ & $156^{\mathrm{a}}$ & 7.19 & $<0.001$ \\
Lactic acid (\% of DM) & $0.25^{\mathrm{a}}$ & $0.59^{\mathrm{b}}$ & $0.18^{\mathrm{a}}$ & 0.04 & $<0.001$ \\
$\mathrm{NH}_{3}-\mathrm{N}(\%)$ & $0.78^{\circ}$ & 0.86 & 0.74 & 0.05 & 0.143 \\
\hline
\end{tabular}

Means with different superscripts within rows are significantly different $(P<0.05)$.

Where $4 \mathrm{~L}$ is emergence of 4 leaves/plant, $5 \mathrm{~L}$ is emergence of five leaves and $6 \mathrm{~L}$ is emergence of six leaves.

Table 2 Effects of regrowth stage (leaf appearance) on nutritive value (\% of DM) of silage plantain.

\begin{tabular}{lccccc}
\hline Parameter & $\mathbf{4 L}$ & $\mathbf{5 L}$ & $\mathbf{6 L}$ & SEM & P Value \\
\hline Dry matter $^{1}$ & $38.7^{\mathrm{b}}$ & $28.7^{\mathrm{a}}$ & $32.5^{\mathrm{ab}}$ & 1.33 & 0.002 \\
Organic matter & $85.7^{\mathrm{a}}$ & $88^{\mathrm{b}}$ & $88.5^{\mathrm{b}}$ & 0.53 & 0.012 \\
Crude protein & $13.4^{\mathrm{b}}$ & $13.0^{\mathrm{b}}$ & $11.8^{\mathrm{b}}$ & 0.45. & 0.082 \\
Acid detergent fibre & $33.0^{\mathrm{a}}$ & $36.0^{\mathrm{b}}$ & $39.6^{\mathrm{c}}$ & 0.35 & $<0.001$ \\
Neutral detergent fibre & $45.6^{\mathrm{a}}$ & $48.7^{\mathrm{a}}$ & $52.8^{\mathrm{b}}$ & 0.69 & $<0.001$ \\
Dry matter digestibility & $62.2^{\mathrm{b}}$ & $60.2^{\mathrm{b}}$ & $54.4^{\mathrm{a}}$ & 0.87 & $<0.001$ \\
\hline
\end{tabular}

Means with different superscripts within rows are significantly different $(P<0.05)$. SEM is the standard error of the mean. ${ }^{1}$ Dry matter includes volatile fatty acids and ammonia, and where $4 \mathrm{~L}$ is the emergence of four leaves/plant, $5 \mathrm{~L}$ is emergence of five leaves and $6 \mathrm{~L}$ is emergence of six leaves. aroma of the silage was noted as being either sweet (fermented) or sour (spoiled). Subsamples ( $25 \mathrm{~g}$ ) were sorted into leaf and stem and oven-dried to determine botanical composition. The $\mathrm{pH}$, buffering capacity (BC), lactic acid concentration and $\mathrm{NH}_{3}-\mathrm{N}$ were all determined on fresh silage; $\mathrm{BC}$ (meq/100 g DM) was measured using the titration method of Playne \& McDonald (1966). Briefly, $20 \mathrm{~g}$ of chopped fresh silage was macerated in $250 \mathrm{ml}$ of distilled water and a $\mathrm{pH}$ meter (Thermo scientific, USA) was inserted to record the $\mathrm{pH}$ before titration to $\mathrm{pH} 3$ and 6 using $0.1 \mathrm{~N}-\mathrm{HCl}$ and $0.1 \mathrm{~N}-\mathrm{NaOH}$, respectively. Lactic acid and $\mathrm{NH}_{3}-\mathrm{N}$ were measured using Randox (Rx Daytona, UK).

Dry matter percentage was determined by weighing a $50 \mathrm{~g} \mathrm{FW}$ sample and oven-drying it at $60^{\circ} \mathrm{C}$ for 48 h. Nutritive characteristics were determined by wet chemistry using freeze-dried and ground herbage. Crude protein (CP), neutral (NDF) and acid detergent fibre (ADF) were measured using the method of Van Soest et al. (1991). Dry matter digestibility (DMD) was determined by the in vitro pepsin-cellulase method, modified from Clark et al. (1982).

\section{Statistical analysis}

To compare the effect of regrowth interval on preservation and quality variables, one-way analysis of variance (ANOVA) was performed using GenStat version 18 (VSN International, 2015), where regrowth was the fixed term and silo was the random term. For Study 2, the variables were compared using the splitplot design model with $\mathrm{N}$ fertiliser as the whole plot term and additive as the subplot term and block the random term.

\section{Results}

All silages were dark brown in colour and had a pleasant sweet smell. There was a large percentage of stem which accounted for 50.4, 59.5 and $73.6 \pm 0.04 \%$ of $\mathrm{DM}$ for $4 \mathrm{~L}, 5 \mathrm{~L}$ and $6 \mathrm{~L}$ silages, respectively, in Study 1. In Study 2, the percentage of stem was 72$90 \pm 0.35 \%$ of DM. Mould was estimated to be 20,34 and $47 \%$ of the external surface area for the $4 \mathrm{~L}, 5 \mathrm{~L}$ and $6 \mathrm{~L}$ respectively, and $45-50 \%$ of the surface area, 
in Study 2, although silos with the MOL treatment had the least mould (43\%). The presence of mould was not visually evident in the middle of the bag as signs of mould had disappeared within $2 \mathrm{~cm}$ from the surface.

\section{Study 1}

The mean $\mathrm{pH}$ of plantain silage was 5.2 and was highest for $6 \mathrm{~L}$ (Table 1). Buffering capacity (BC) and lactic acid were highest for 5L $(\mathrm{P}<0.001)$ silage. Across all regrowth stages the average $\mathrm{CP}$ content was less than $14 \%$ and DMD was less than $65 \%$. However, DMD was highest at earlier stages of regrowth (4L and $5 \mathrm{~L}$ ) (Table 2). Increasing the regrowth interval increased $\mathrm{ADF} \%$ of plantain silage and the NDF levels at $4 \mathrm{~L}$ and $5 \mathrm{~L}$ were lower than for $6 \mathrm{~L}$. There were no differences in CP contents across treatments.

\section{Study 2}

There was no interaction between fertiliser and additives for silage characteristics (Table 3). However, additives reduced $\mathrm{pH}$ compared to $\mathrm{CON}$. The higher $\mathrm{N}$ fertiliser also resulted in lower $\mathrm{pH}$. Average lactic acid was $0.54 \%$ and was greater by increasing fertiliser and by using MOL or BIO. By comparison, $\mathrm{NH}_{3}-\mathrm{N}$ was low at an average of $0.57 \%$ and was increased by extra fertiliser and reduced by MOL.

The average $\mathrm{CP}$ content was $11.6 \%$ and DMD averaged $50.7 \%$ (Table 4). There was no interaction between additive and fertiliser on nutritive value of plantain silage (Table 4). Increasing $\mathrm{N}$ fertiliser reduced
Table 3 Effect of additives and fertiliser on plantain silage $\mathrm{pH}, \mathrm{BC}(\mathrm{meq} / 100 \mathrm{gDM})$, lactic acid concentration (\% of DM) and $\mathrm{NH}_{3}-\mathrm{N}(\%)$.

\begin{tabular}{|c|c|c|c|c|c|}
\hline Fertiliser & Additive & $\mathrm{pH}$ & $\mathrm{BC}$ & Lactic acid & $\mathrm{NH}_{3}-\mathrm{N}$ \\
\hline \multirow[t]{4}{*}{$20 \mathrm{~N}$} & $\mathrm{CON}$ & 6.30 & 256 & $0.23^{d}$ & $0.52^{a b}$ \\
\hline & $\mathrm{BIO}$ & 5.63 & 201 & $0.65^{a b c}$ & $0.56^{a b}$ \\
\hline & ENZ & 6.18 & 270 & $0.52 \mathrm{abcd}$ & $0.45^{b}$ \\
\hline & MOL & 5.39 & 212 & $0.48^{a b c d}$ & $0.65^{a b}$ \\
\hline \multirow[t]{4}{*}{ 20NPK } & CON & 6.43 & 297 & $0.45^{b c d}$ & $0.50^{a b}$ \\
\hline & $\mathrm{BIO}$ & 5.71 & 282 & $0.79^{a b}$ & $0.43^{b}$ \\
\hline & ENZ & 5.86 & 322 & $0.23^{d}$ & $0.57^{a b}$ \\
\hline & $\mathrm{MOL}$ & 5.75 & 267 & $0.82^{a}$ & $0.74^{a}$ \\
\hline \multirow[t]{4}{*}{ 40NPK } & $\mathrm{CON}$ & 5.89 & 304 & $0.41^{\mathrm{cd}}$ & $0.61^{a b}$ \\
\hline & $\mathrm{BIO}$ & 5.31 & 298 & $0.56^{\mathrm{abcd}}$ & $0.58^{a b}$ \\
\hline & ENZ & 5.58 & 351 & $0.68 \mathrm{abc}$ & $0.71^{a}$ \\
\hline & MOL & 5.40 & 217 & $0.62 \mathrm{abc}$ & $0.52^{a b}$ \\
\hline \multirow[t]{2}{*}{ SEM } & & 0.87 & 36.3 & 0.11 & 0.08 \\
\hline & Fertiliser & 0.02 & 0.04 & 0.33 & 0.30 \\
\hline \multirow[t]{2}{*}{$P$ value } & Additive & $<0.001$ & 0.003 & 0.004 & 0.06 \\
\hline & $A \times F$ & 0.66 & 0.57 & 0.035 & 0.009 \\
\hline
\end{tabular}

Means with different superscripts within columns are significantly different $(P<0.05)$. Where $20 \mathrm{~N}$ is Nitrogen applied at $20 \mathrm{~kg} \mathrm{~N} / \mathrm{ha} ; 20 \mathrm{NPK}$ is N P K (20:1:15) and 40NPK is NPK (40:1:15)

Where CON is Control, BIO is Biosil, ENZ is Enzyme, MOL is molasses.

Table 4 Effect of additive and fertiliser on nutritive value characteristics (\% of DM) for plantain silage.

\begin{tabular}{lccccccc}
\hline Fertiliser & Additive & DM & OM & CP & ADF & NDF & DMD \\
\hline $20 N$ & CON & 27.3 & 90.8 & 11.1 & 40.8 & 56.5 & 50.7 \\
& BIO & 27.9 & 90.6 & 10.9 & 41.1 & 56.7 & 50.2 \\
& ENZ & 29.1 & 90.2 & 11.4 & 42.4 & 57.0 & 50.5 \\
\multirow{2}{*}{ 20NPK } & MOL & 28.4 & 90.3 & 11.1 & 41.3 & 54.5 & 52.8 \\
& CON & 25.6 & 90.1 & 11.7 & 43.0 & 57.4 & 50.8 \\
& BIO & 25.1 & 89.9 & 12.2 & 41.9 & 56.7 & 52.1 \\
& ENZ & 24.8 & 90.0 & 11.9 & 43.9 & 58.1 & 49.7 \\
$40 N P K$ & MOL & 25.5 & 90.7 & 11.5 & 40.6 & 55.4 & 49.5 \\
& CON & 23.9 & 90.3 & 11.4 & 41.6 & 58.1 & 48.3 \\
& BIO & 24.6 & 89.7 & 12.6 & 41.1 & 54.5 & 51.9 \\
& ENZ & 23.9 & 90.0 & 11.7 & 43.8 & 57.4 & 48.7 \\
\multirow{2}{*}{ SEM } & MOL & 26.5 & 90.4 & 11.4 & 40.9 & 54.4 & 53.8 \\
& & 1.19 & 0.34 & 0.44 & 0.87 & 0.98 & 1.29 \\
\hline \multirow{3}{*}{ P value } & Fertiliser & $<0.001$ & 0.24 & 0.08 & 0.31 & 0.49 & 0.84 \\
& Fe x Ad & 0.81 & 0.71 & 0.77 & 0.72 & 0.63 & 0.15 \\
\hline
\end{tabular}

Where: DM is dry matter; OM organic matter; CP crude protein; ADF acid detergent fibre, NDF neutral detergent fibre and DMD in vitro dry matter digestibility; $20 \mathrm{~N}$ is nitrogen applied at $20 \mathrm{~kg} \mathrm{DM} / \mathrm{ha}$. 20NPK, N P K (20:1:15) and 40NPK, NPK (40:1:15). CON is Control, BIO is Biosil, ENZ is Enzyme and MOL is molasses. 


\section{Discussion}

\section{Preservation characteristics}

Well fermented ryegrass silages should have a $\mathrm{pH}$ of 3.5-4.5, however, a survey by Howse et al. (1996) of pasture silages revealed the typical $\mathrm{pH}$ tended to be between 4.5 and 5.0. Plantain silage in this study, had a higher $\mathrm{pH}$ ranging from 5.0 to 6.4. The high initial $\mathrm{pH}$ may have inactivated plant proteases, reduced the extent of protein degradation maintaining a higher $\mathrm{pH}$. Restriction of proteolysis caused by anti-microbial compounds such as aucubin or acteoside (Isselstein 1993a,b; cited by Stewart 1996) may have limited microbial activity and/or the slow degradability of plant proteins. Evidence of slow protein degradation by rumen bacteria has also been demonstrated for in vitro fermentation studies (Naverette et al. 2016). However, the production of $\mathrm{NH}_{3}-\mathrm{N}$ in this study was low compared with many ryegrass-based silages (Howse et al. 1996). Low concentrations of ammonia are indicative of good quality silage as less $\mathrm{N}$ has been lost. Also, increasing the $\mathrm{N}$ fertiliser rate appeared to improve fermentation characteristics, as $\mathrm{pH}$ was lowest when 40 compared with $20 \mathrm{~kg} \mathrm{~N} / \mathrm{ha}$ was applied. This response may be due to the increased $\mathrm{N}$ available for LAB (Lactic Acid Bacteria) or increased moisture content with the higher $\mathrm{N}$ fertiliser reducing $\mathrm{DM} \%$, making fermentation conditions more favourable.

Achieving low $\mathrm{pH}$ in silage requires rapid growth of $\mathrm{LAB}$ and the subsequent production of lactic acid. Lactic acid is needed to decrease $\mathrm{pH}$ (Muck 2004) and $\mathrm{BC}$ (Pahlow et al. 2003). Low $\mathrm{pH}$ and $\mathrm{BC}$ improves the aerobic stability of silage when exposed to air (Muck 2004). In this study, the high $\mathrm{pH}$ corresponds with the low lactic acid concentrations of less than $1 \%$ of DM. Growth of LAB may have been inhibited either by the lack of supply of either sugars or protein or both. Readily fermentable carbohydrates are the main energy source for LAB. Previous studies have reported low water soluble carbohydrates in plantain (Navarette et al. 2016). A deficiency in fermentable sugars was indicated by the positive response to the addition of molasses in the current study, which resulted in an increase in lactic acid with a drop in $\mathrm{pH}$.

The availability of substrates for LAB is also influenced by cell rupture during the ensiling process. In this study, plantain was not macerated which may have slowed the availability of substrates. In preliminary investigations (3 months prior), comparing chopping lengths, showed little difference in looks or smell of mini-silos after 90 days. Because most commercial mowers do not chop forage this research replicated silage making as occurs at a commercial level. Although our results suggest there was little activity from $\mathrm{LAB}$, the sweet smell of the silage indicated it was not spoiled. Anecdotal observations after feeding the silage to stock confirmed acceptable palatability.

\section{Nutritive value of plantain silage}

Overall, the quality of plantain silage was poor with $\mathrm{CP}$ content less than $14 \%$ and DMD under $65 \%$, even for the youngest plantain (4L). However, the DMD of the silages in this study at the early growth stage (4L and 5L, Table 2) are similar to published values for DMD of ryegrass (62\% DMD) and lucerne (61\% DMD) silage stored for 42 days (Raeside et al. 2012). The low digestibility of the plantain silage in this study is likely explained by the high content of NDF which in both Study 1 and 2 exceeded $40 \%$ of DM. For the current study, herbage was harvested in December when seed head was prevalent, particularly at the later leaf stages and this likely contributed to high NDF and poor DMD. The negative effect of flowering on silage quality was also noted by Howse et al. (1996) in a survey of ryegrass-based silages, reporting that harvests occurring after November were of poorer quality as seed head started to develop.

The reduction in DMD with advancing maturity, as leaf appearance increased, was not unexpected as Lee et al. (2015) observed that younger plantain leaf and stem are higher in digestibility than that of older material. With regards to additives, there was little difference in DMD among treatments, but a marginal improvement in DMD when molasses was added might be explained by a dilution effect of sugars over fibre as NDF was reduced by MOL.

The implications of low CP under all management regimes trialled here may present some advantages in terms of a late-season low- $\mathrm{N}$ feed to reduce $\mathrm{N}$ intake and subsequent urinary $\mathrm{N}$ losses. From an environmental point of view, plantain silage may offer benefits as a low $\mathrm{N}$ supplement in autumn which is likely to be cheaper than alternative bought-in feeds. Furthermore, plantain silage has fewer health risks compared to high sugar crops such fodder beet (Beta vulgaris). Future research should focus on improving the digestibility of plantain silage.

\section{Conclusions}

The fermentation characteristics of plantain minisilos did not follow conventional rules for adequate fermentation yet the odour characteristics indicated that the silage was not 'spoiled'. Additives and fertilisers, which improved conditions for lactic acid bacteria, did improve the preservation characteristics. Delaying harvest from four to the six leaf growth stage reduced silage quality because of a lower CP and DMD; this reduction in quality was not offset by using additives or fertiliser once seed head was prevalent at the sixth leaf stage. The poor quality of plantain silage demonstrated 
in this study suggests it would not be suitable as a supplement in early lactation, but it could be fed to cows in autumn to reduce $\mathrm{N}$ intake and to aid drying-off.

\section{REFERENCES}

Bolsen, K.; Ashbell, G.; Weinberg, Z. 1996. Silage fermentation and silage additives - review. Asian Australasian Journal of Animal Sciences 9: 483-494.

Box, L.A.; Edwards, G.R.; Bryant, R.H. 2016. Milk production and urinary nitrogen excretion of dairy cows grazing perennial ryegrass-white clover and pure plantain pastures. Proceedings of the New Zealand Society of Animal Production 76: 18-21.

Box, L.A.; Edward, G.R.; Bryant, R.H. 2017. Diurnal changes in the nutritive composition of four forage species at high and low $\mathrm{N}$ fertiliser. Journal of New Zealand Grasslands 79: 103-110.

Chamberlain D.G.; Robertson, S. 1992. The effects of the addition of various enzyme mixtures on the fermentation of perennial ryegrass silage and on its nutritional value for milk production in dairy cows. Animal Feed Science and Technology 37: 257-264.

Clark, T.; Flinn, P.C.; McGowen, A.A. 1982. Low cost pepsin-cellulase assays for prediction of digestibility of herbage. Grass and Forage Science 37: 147-150.

Dairy NZ. 2006. What is high quality pasture silage? Accessed: 23rd May 2018 http://www.dairynz.co.nz/ media/

Howse, S.W.; Isherwood, P.; Miller, D.B.;Wells, J.L.; Riddick, C.M.; Thomson, N.A.; Clark, D.A. 1996. Pasture silage in New Zealand - targets and current practice. Proceedings of the New Zealand Grassland Association 57: 157-160.

Isselstein, J. 1993a. Forage nutritive value and ensilability of some common grassland herbs. Proceedings of the 17th International Grassland Conference: $577-578$.

Isselstein, J. 1993b. Untersuchungen zum futterwert und zur konservierungseignung verbreiteter grunlandkrauter, Mitt. Ges.Pflanzenbauwiss 6: 8992.

Jacobs J.L.; McKenzie F.R.; Rigby S.E.; Kearney G. 1998. Effect of nitrogen fertiliser application and length of lock up on dairy pasture dry matter yield and quality for silage in South-Western Victoria. Australian Journal of Experimental Agriculture 38: 219-226.

Kleinmans, J.J.; Dewar, W.R.; Erasmus, H.J.H.; Densley, R.J. 2011. Using silage inoculants to improve the quality of pasture and maize silage in New Zealand. Proceedings of the NewZealand Grassland Association 73: 75-80.

Lee, J.M.; Hemmingson, N.R.; Minneé, E.M.K.; Clark, C.E.F. 2015. Management strategies for chicory (Cichorium intybus) and plantain (Plantago lanceolata): impact on dry matter yield, nutritive characteristics and plant density. Crop and Pasture Science 66: 168-183.

Moran, J. 2005. Tropical dairy farming: feeding management for small holder dairy farmers in the humid tropics. Landlinks Press. Collingwood, Vic. 295 pp.

Muck, R.E. 2004. Effects of corn silage inoculants on aerobic stability. American Society of Engineers 47: 1011-1016.

Navarette, S.K.; Kemp, P.D.; Pain, S.J.; Back, P.J. 2016. Bioactive compounds, aucubin and acteoside in plantain (Plantago lanceolata $\mathrm{L}$ ) and their effect on in vitro rumen fermentation. Animal Feed Science and Technology 222: 158-167.

Pahlow, G.; Muck, R.E.; Driehuis, F.; Elferink, S.J.W.H.O.; Spoelstra, S.F. 2003. Microbiology of ensiling. pp. 31-93. In : Silage science and technology. (Eds.) Buxton, D.R.; Muck R.E.; Harrison, J.H. American Society of Agronomy, USA.

Playne, M.; McDonald, P. 1966. The buffering constituents of herbage and of silage. Journal of the Science of Food and Agriculture 17: 264-268.

Raeside, M.; Nie, Z.; Lamb, J.; Byron, A.; Behrendt, R. 2012. Nutritive value of silage from perennial ryegrass, plantain and lucerne pastures in south west Victoria. Proceedings of the 16th Australian Agronomy Conference. pp. 1-4.

Stewart, A. 1996. Plantain (Plantago lanceolata) - a potential pasture species. Proceedings of the New Zealand Grassland Association 58: 77-86.

Tengerdy, R.; Weinberg, Z.; Szakacs, G.; Wu, M.; Linden, J.; Henk, L.; Johnson, D. 1991. Ensiling alfalfa with additives of lactic acid bacteria and enzymes. Journal of the Science of Food and Agriculture 55: 215-228.

Van Soest, P.J.; Robertson J.B.; Lewis B.A. 1991. Methods for dietary fibre, neutral detergent fibre and non-starch polysaccharides in relation to animal nutrition. Journal of Dairy Science 74: 3583-3597.

Woods, R.; Cameron, K.; Edwards, G.; Di, H.; Clough, T. 2016. Effects of forage type and gibberellic acid on nitrate leaching losses. Soil Use and Management 32: $565-572$. 
